\title{
Management of Fire Arm Injury chest, an experience of 10,200 patients
}

\author{
Amer Bilal \\ From World Society of Cardiothoracic Surgeons 25th Anniversary Congress, Edinburgh \\ Edinburgh, UK. 19-22 September 2015
}

\section{Background/Introduction}

Firearm injury chest are among the most common and leading cause of trauma along with roadside accidents in tertiary care hospitals around the world. The situation in the developing world, including Pakistan, is even worse where terrorism, poverty, social inequality, unemployment and access to the illegal weapons are obvious.

\section{Aims/Objectives}

To determine the surgical management of fire arm injury chest.

\section{Method}

An observational descriptive study was conducted in the department of Thoracic Surgery, Postgraduate Medical Institute, Lady Reading Hospital Peshawar from June 2002 to Dec 2014. The record of all trauma patients that had fire arm injuries undergoing surgical intervention over a period of twelve years was reviewed.

\section{Results}

The study included 10,200 patients; all were having firearm injuries leading to hemopneumothorax. Male to female ratio was $2: 1$. All patients were initially managed with tube thoracostomy. 400/10200 (3.92\%) patients underwent emergency Thoracotomy, Rest of the patients i.e. 9801/10200 (96.07\%) were hemodynamically stable and treated with low pressure suction and incentive spirometry. In 550/10200 (5.39\%) patients which developed clotted hemothorax were evacuated successfully through thoracotomy. The mean time interval between injury and thoracotomy was 14.5 days (range between 11-124 days). The mean volume of clotted hemothorax evacuated was $650 \mathrm{ml}$.The mean post-operative hospital stay was 5 days.

Dept of Cardiothoracic Surgery, Lady Reading Hospital, Peshawar, Pakistan

\section{Discussion/Conclusion}

Majority of fire arm injuries were successfully managed by chest intubations, observation and supported treatment. 400 patients required emergency Thoracotomy, 550 patients went into develop clotted Hemothorax requiring evacuation

Published: 16 December 2015

doi:10.1186/1749-8090-10-S1-A15

Cite this article as: Bilal: Management of Fire Arm Injury chest, an experience of 10,200 patients. Journal of Cardiothoracic Surgery 2015 10(Suppl 1):A15.
Submit your next manuscript to BioMed Central and take full advantage of:

- Convenient online submission

- Thorough peer review

- No space constraints or color figure charges

- Immediate publication on acceptance

- Inclusion in PubMed, CAS, Scopus and Google Scholar

- Research which is freely available for redistribution

\section{() Biomed Central}

